\title{
Labour Policies of a neo-Fuhrer State: The Nigerian Case
}

\author{
'Jimi O. Adesina \\ Department of Industrial Sociology, Rhodes University, \\ Grahamstown, South Africa ${ }^{l}$
}

\begin{abstract}
This paper examines the labour dimension of the Nigerian state in the period between 1994 and 1998 and argued that it is important to understand the unique nature of the state during this period. While Nigeria was not strange to authoritarian states, the specific mode of constitution of the state during the period requires specific codification-hence the idea of a neo-Fuhrer State. While it is common to analyse the form of constitution of the state during this period as an aberrant form, we argue that the basis and justification of dictatorship was laid by the political content of implementing the set of neo-liberal policies that underscored Structural Adjustment Programme. It is in analysing the labour policies of the neoFuhrer State that we appreciate this. The paradox of the nature of response to autocracy at the time is binary: acquiescence on the part of senior union leaders and robust shop floor resistance on the other hand. This is the aspect of the political history of the period that is hardly emphasised and poorly understood. This paper serves as a corrective to both my earlier analysis and the historiography of the period.
\end{abstract}

\section{Introduction}

For the greater part of the late 20th century, the relationship between the State and Unions in Nigeria has been defined by autocracy and neo-liberalism: the parsimony of the military regimes and the global demand for neo-liberal macroeconomics and social policies. The wholesome adoption of neo-liberalism changed the rules of engagement between unions and the State, largely because the assumptions underscoring neoliberalism made it easy for the state to initiate and justify repression (cf. Adesina, 2000). The international politics of adjustment also meant that there was considerable silence and blindness to the initial stirrings of the dictatorship that would later engulf Nigeria.

The authoritarianism of the Babangida and Abacha regimes had profound impact on the trade unions at the level of the top leadership of the unions (something I refer to as "behaviour modification" under the impact of state repression). Repression produced acquiescence and sometimes 'cold complicity' with an increasingly neo-Fuhrer state among senior trade 
union officials. However, this period witnessed two opposing trends: considerable acquiescence at the level of national leadership and heightened militancy at the shopfloor level and among some white-collar unions. The latter involved a vigorous contestation of the policy terrain with the State.

In section two of this paper we examine the linkages between neo-libcralism and autocracy to highlight the extent to which the politics of adjustment made the virulent dictatorship of the late 20 century possible. Viewed from this angle the emergence of the neo-Fuhrer state under the dictatorship of Sani Abacha is a continuation of the repression of the preceding years not its disruption. In section three, we examine the distinct nature of Sani Abacha's neo-Fuhrer project: even in its virulence, it was concerned with constructing a hegemonic project. This is something that is often neglected in the account of this period. We also outline the content of the labour policies of the regimewhich was both repressive yet oriented towards constructing hegemony. In section four we examine the forms of labour response from the labour movement: the duality of acquiescence of the top echelon of the trade union leadership and heightened militancy at the shop-floor and among some white collar unions.

\section{Neo-liberalism, Dictatorship and Labour}

In an earlier work (Adesina, 2000), I outlined the links between neo-liberalism and dictatorship in Nigeria in the period 1985 and 1994. At the heart of that discussion are some important issues that are germane to our discussion here. First is that neo-liberalism (or structural adjustment) altered the rules of engagement between the state and the unions in Nigeria (as it did the larger civil society). Ideologically, in rendering the labour movement as a culprit in rent seeking and urban bias of the development strategy, neoliberalism conferred legitimacy on the repression of unions and union activists.

In the mirror of neo-liberal economics, organised labour are cartels interfering with the normal functioning of the market, forcing employers to pay wage rates above what the market can clear. Dismantling organised labour opposition did not only make political sense... but economic sense, as well. It is in this sense that the fundamental changes in the landscape of organised labour in Nigeria... make sense (Adesina, 2000: 142-143).

Again, to reiterate a point made elsewhere (Adewumi \& Adesina 1999), it is difficult separating the politics of adjustment from the politics of personal rule and self perpetuation in power that Ibrahim Babangida initiated with a highly convoluted 'transition`programme' to civil rule. It is important to separate the two, but to also emphasize the extent to which the 
politics of adjustment mobilised international support in Europe and North America for a clearly repressive regime, because it was considered committed to implementing a neo-liberal agenda. To correct the potential one-sided discussion of an earlier work (Adewumi and Adesina, 1999), I should also stress that the politics of adjustment provided the enabling environment that translated neo-fascism into economically justifiable projects. In altering the terms of social discourse, so profoundly, adjustment facilitated the repression of trade unions and the impoverishment of the mass of wage-dependent households. The diplomatic support that the Babangida regime received from the West, because of its adopti0n of the structural adjustment programme, eliminated the external diplomatic of economic constraints that might have forced it to respect the basic rights of unions. Neo-liberalism undermined the struggle for democracy in Nigeria in this period because it cast all the institutions of civil society, necessary to tame a ravaging state, in the mould of policy-distorting, rent-seeking and negative forces. In this sense the emergence of Abacha's neo-Fuhrer state was an extension of this repressive atmosphere, rather than a break.

\section{Trade Unions and the Neo-Fuhrer State}

I will suggest that it is in the light of the above that we should understand the labour policy of the Abacha regime. More than ever before, there would seem the need for the regime to ensure a total control or domination of the labour movement.

\section{An Outline of a neo-Fuhrer Project ${ }^{2}$ :}

I suggest that in understanding the making of the Abacha regime, and its construction of a neo-Fuhrer project, we delineate three major phases. These phases and the specific character of the Nigerian state that compels me to replace the "Nigerian" with 'Abacha' are crucial for my analysis. 1 would like to suggest the three main phases in the emergent character of the slate as follows:

The first is the tentative phase of trying to scoop up legitimacy. Roughly this phase ran from November 1993 to May 1994. This phase involved the manoeuvring by the principal elements within the regime to negotiate its existence with the members of the political class. The military regime needed the support of the politicians and remnants of the military loyal to Ibrahim Babangida (the so-called TBB boys') to establish itself. The second phase ran, roughly, from June 1994 to March 1996. This phase involved one of consolidating its grip on power. This consolidation phase involved the pervasive use of repression against perceived and real enemies. At the same time, the regime tried to create major inroad into the civil society through the sponsorship of groups that were meant to be forerunners for its objective of constructing 'spontaneous consent' for itself. The 
brutality of the regime's phase two remains a clear marker for the neo-Fiihrer agenda in Nigeria. It also has a great resonance within the institutions of civil society and the sense of powerlessness in several quarters, not the least in the leadership of the labour movement. A key aspect of a neo-Fiihrer state is not only the concept of a "strong leader", often with militaristic thrust, which it embodies in its public expression of power, but an attempt to completely create society in its own image.

Grafted onto the second phase of the regime is the third phase with its effort at constructing "spontaneous consent" for itself. It is defined by the regime's response to domestic and international disapproval of its violation of human rights and civil liberties and involved a concerted effort to court and construct a hegemonic agenda within the civil society and with the international financial institutions - without ending arbitrary arrest and detention. Furthermore, it is defined by an advancement of the objective of the retention of state power.

Its neo-Fiihrer essence was reinforced in the combination of personal exercise of power and the consolidation of state power around the person of Sani Abacha. The overall tenor of the regime involved a shift in the policy-making process, namely the replacement of articulated institutions of governance with individual exercise of power by state functionaries. The consolidation of personal power and absence of collective organs of policy-making was itself dysfunctional for the policy-making process: officials are constantly second-guessing the head of the regime and acting in the way they assume he would. This neo-Fiihrer regime was everything but "suspended in mid-air:" if anything it was underwritten by distinct configuration of local and international economic (class) and ethnic interests.

\section{Trade Union Policies of a neo-Fiihrer State:}

The first major test of the regime's response to labour came in the aftermath of the strike actions in July and August 1994. In addition to the arrest of the NUPENG and PENGASSAN ${ }^{3}$ leadership, the offices of the unions and the Nigeria Labour Congress were hijacked by the State. In the violation of the property rights of the unions and the Congress, the provisions of at least two ILO Conventions, and of the African Charter of Human and Peoples' Right, were violated. In addition, the military regime appointed sole administrators to run the affairs of the unions and the Congress. It is instructiveand perhaps a measure of the regime's insensitivity to the multi-cultural nature of the Nigerian polity - that all the administrators appointed so far came from the Northern region of the country. The implication for the pan-Nigerian platform on which the Nigerian labour movement has historically operated is profound, indeed. Furthermore, in spite of the several promises made to the International Labour Organisation to return the unions to their members, this did not 
happen in the lifetime of the regime; elections were never organised even in the cases of NUPENG and PENGASSAN.

It is perhaps from the perspective of the deployment of its legislative power that the Abacha State has been most revealing in its response to trade unions. In this respect, we will concern ourselves with the four main decrees on the trade unions in 1996. These are:

1. Trade Union (Amendment) Decree 1996 (No. 4 of 5 January).

2. Trade Disputes (Essential Sen-ices Deregulation, Proscription and Prohibition from Participation in Trade Union Activities) Decree 1996 (No. 24 of 21 August).

3. Trade Unions (Amendment) (No. 2) Decree 1996 (No. 26 of 16 October).

4. Trade Unions (International Affiliation) Decree 1996 (No. 29 of 23 October).

For the purpose of our analysis, we will look at the broad objectives of the decrees, some of their specific provisions, their implications, and the response of the leadership of the labour movement. Decrees 4, signed into law on 5 January 1996, gave legal backing to the restructuring of the 41 labour unions to 29 through merger and a clearer demarcation of the jurisdiction of each of the new unions. Decree 4 simplified the procedure for merger between trade unions, amending the provisions of the 1973 Trade Union Act. However, while the restructuring of the labour unions is the stated objective, the two decrees went beyond this. The provisions of Decree 4 went on to define new framework for affiliation with participation in, and funding of the Nigeria Labour Congress and the new unions. Decree 4 replaced the provisions of the Trade Union Act of 1973 with a more 'simple' procedure. The Trade Union Act of 1973 required, among other things, that in case of a union merger the delegates' conference of the merging unions will meet separately and vote on the merger proposal. By contrast, the amendment in Decree 4 only required, "a resolution... signed by the President or the secretary of the merging unions" (S.27 (1)(a)). The resolution is presented to the Registrar of Trade Unions along with "the rules proposed for the merging unions and the terms of the merger" (S.27 (1)(b)). Once unions have complied with these provisions "the Registrar shall forthwith register the merged unions" (S.27 (3)). In a sense, the two officials of the merging unions could decide on a merger, without consultation with the rank-andfile of the members. This would be a profound curtailment of the democratic principle of union organisation.

If the regime was 'lending' union leaders some of its autocratic power, there was to be a sting in the tail. Section 33 of the 1973 Act was amended to include a new subsection 7. This new sub-section barred non-members of unions from contesting any elective office of the Nigeria Labour Congress (NLC) "or any of the trade unions". A "member of a trade union" was defined as "a card carrying member of a union who contributes 
money to the union as required under section 15" (amended Section 52). In essence, what the regime did was to prevent full-time union officials (General Secretaries, etc.) from contesting any elective post into the NLC, which meant positions like the NLC President, Deputy President, etc. Since 1984, full-time officials have played an increasingly important role in the elective positions of the NLC, and by 1988, the top elective positions in NLC were held by full time officials of affiliate unions. By 1995, the repository of leadership capabilities in the labour movement lied with full time officials. In spite of the crisis that engulfed the labour movement, the most articulate Opposition came from the full time officials. This category of unionists usually has the experience, confidence, and material position to stand-up to the regime. This was the cadre of unionists that the decree sought to exclude from the elective posts in the NLC whenever the regime decided to release the labour centre to the workers who own it. We should note that unlike the elective posts in its affiliate unions, the elected officials of the NLC are full-time officers of the Congress.

The full time union officials read the decree mainly from the perspective that they were barred from standing for elective posts in the NLC. The feeling that the regime was going to honour" its promise to the ILO-i.e., to return the NLC to the unions and allow democratic elections into its various offices - fuelled this reaction. In reacting to the decree the senior full time officials make a distinction between General Sani Abacha and his Minister of Labour, Mr. Uba Ahmed. The decree, they argued, was part of the Minister's efforts to prevent them from contesting the elective positions and to sponsor his cronies. This was after one year of active collaboration between the unionists and the Minister, during which the unionists thought that by being 'non-confrontational' they -could persuade the regime that they were not part of the political opposition. The collaboration included participating in drafting the decree - although the provisions they objected to were later added by the regime's officials.

By early 1996 the rancour between the unionists and the Minister was becoming news items. Earlier, we mentioned the emergence of a neo-Fuhrer state with its problem for the statutory organs of decision-making. The illusion that this sometimes created for elements in the civil society was to believe that Abacha could be persuaded to arbitrate in their favour when they have disagreements with his functionaries. The unionists fell into the same illusion. For several months, after the decree was published the most senior general secretaries focused their energies at reaching General Abacha, hoping they could persuade him to see their points of view. Such a meeting was arranged in August 1996 at which Abacha extracted support for his regime and the 'transition' programme ${ }^{\wedge}$ fronrthe unionists. Decree 4 was part of a strategy of securing a trade union movement that was bent to the will of the regime and its Fuhrer.

If the unionists thought the regime would relent in hamstringing 
their activities because they swore allegiance to the neo-Fiihrer, they were to be disappointed. Decree 26 was signed into law on 16 October 1996,. Rather than reverse the provisions of Decree 4, the decree further tightened the restrictions and added new ones. The decree included the following:

1. Further restrictions on the definition of non-members of trade unions to cover not just those who do not pay union dues, but those who are not "normally engaged in the trade or industry which the trade union represents" (Para. 8, First Schedule).

2. It became a criminal offence for anyone who was not a "card-carrying member of any trade union to participate and assume a functional role in any of the policy or decision making organs and committees, or formations (by whatever name called) within the union or the Central Labour Organisation except if the function is strictly limited to administrative duties only" (new S. 33(8)) (Italics mine). It restricted the ability of fulltime officials to make policy in their own unions - much less the NLC. The punishment for contravening this new law was a fine of N100, 000 or five years imprisonment or both (S.33(9)), and the union losing its registration.

3. It made a 'no-strike' clause mandatory for all collective agreements (amended S.I6A). Where unions, go on strike, the deduction of check-off dues and remittance to the union by the employer would be terminated (S. 16A(b); S. 17 (4).

4. It removed the powers of the High Court, as defined in Sections 5 \& 7 of the 1973 Trade Union Act, to hear appeals against a refusal to register a union or (a proposed) cancellation of union registration, respectively. The Minister of Labour was substituted for the High Court. In addition, the Minister could for reasons of "overriding public interest" revoke the certificate of registration of any trade unions (S.7 (9)).

If the unionists still had any illusion about whether the Minister had been acting on behalf of his Fiihrer all along or not, Decree 26 was a possible cure. Clearly, the regime was not placated by whatever commitment of loyalty or allegiance the unionists made. It is all the more instructive that the new S.33 (8) to (10) were in response to the National Union of Textile Garment and Tailoring Workers (NUTGTW). The union had sought to blunt the impact of Decree 4 by formally adopting its full time officials as union members! The officials also started paying check-off dues. Quite instructive about the NUTGTW is that its General Secretary and senior officials continued to believe that acquiescing with the regime was the only option opened to them (see section 4 below).

Decree 29 was ostensibly signed into law on 23 October 1996, but was not made public until April 1997. In essence, the decree barred all trade unions and the labour centre in Nigeria from affiliation with any 
international labour organisation, unless "a specific application" has been made to, and has received "approval [from] the Provisional Ruling Council" (S.3 (lc)). The decree exempted the Organisation of African Trade Union Unity (OATUU) and the so-called Organisation of Trade Unions for West Africa from such blanket ban. All existing affiliations "shall cease"! It should be noted that the 'specific application' should be made "to the Minister in the appropriate manner stating such particulars as the Minister may, from time to time, apply" (S.3 (2)). This gave the Minister power to shift the goal post should the need arise. As with Decree 26, contravention of the decree would not only draw a fine of $\mathrm{N1} 00,000$ or a five year jail sentence, or both; but the union "shall have its certificate revoked". ${ }^{4}$

If the earlier discussion was about the trade unions generally, Decree 24 of August 1996 was in response the Academic Staff Union of Universities (ASUU). The union had gone on strike over the regime's refusal to re-negotiate a 1992 Collective Agreementon the funding of universities and pay and conditions of employment - between it and the Federal government. The 1992 agreement provided for the renegotiation of the terms at the expiration of the collective contract. After, a month, preliminary negotiation started. However, on 15 May 1996, during the preliminary talks the Minister of Education issued a press statement 'dissolving' the national union. In a sense, the regime proscribed the party with whom it was in discussion - ostensibly, that the problem will go away. Again, many in union (leadership and membership) fell into the same illusion that the Minister was acting contrary to the position of his Fuhrer. The problem was how to explain why General Abacha would not replace the Minister or give contrary instructions. Decree 24 was the formalisation of the proscription of the union. Interestingly, the decree was published on the same day the leadership of the union was to hold a meeting with senior officials of the regime in the Presidential Villa in Abuja - the official residence of the Fuhrer.

The decree proscribed the National Executive Council and the Branch Executive Committees of all the unions in Nigerian universities and prohibited them from "participating in any trade union activities in Nigeria (S.I). The decree went on to "dissolve" the two organs and removed the union officials from office (S.2 (1) and (2)). Contravening the law would draw a fine of N100,000, a 3 years jail sentence, or both. However, the decree added another clause. Section 2(3) made it "unlawful for any of the Unions or Association... to operate other than the Campus of a university" (emphasis mine). It became the basis of a legal challenge by a branch of the union. The Federal High Court in Enugu ruled, on 15 April 1997, that with the provision of Section 2(3) "the proscription of the Union under Section $1 \ldots$ is not total". ${ }^{5}$ The union could operate on individual campuses. 


\section{Duality of Union Response}

From the perspective of the evolving agenda of a neo-Fiihrer State, the objectives of the executive and legislative actions of the regime are quite clear. The NLC and the trade unions, even in its post-1988 state, still represented a restive force within the civil society - with the potential to challenge and undermine the regime. Even with a leadership that had been compromised, the regime considered the trade union movement a 'dangerous' front. The regime was not particularly mistaken in its perception. Even with Paschal Bafyau, as the Congress President, the NLC functioned as a rallying point for militant action by civil society activists. The potential threat that the trade union movement carried, qua trade union, was the primary source of the greatest crisis that the regime ever faced - in widespread strike action of June-August 1994, for which the position of the oil workers and staff was most openly political. ${ }^{6}$ The objective of the decrees and legislative action was to weaken and demobilise the unions as a possible opposition front. As the brutality of the regime unfolded, it became an important strategy for 'behaviour modification' among 'unionists. ${ }^{7}$ It is to this that I wish to touch briefly.

In the lead-up to the NLC elections in November 1988, several senior union officials - mostly the full time officials - agreed to put up Paschal Bafyau as the sole candidate because in the words of one of the public sector union general secretaries, he was the candidate acceptable to the regime of Ibrahim Babangida (cf. Otobo, 1992a, $1992 \mathrm{~b}$ for background accounts). With dictatorship flowering into neo-fascism in the late 1990s, acquiesce with the regime became the option that many union leaders took. For most of the union leadership this involved withdrawal from the 'political terrain' and anything that smacks of union militancy. For some, acquiescence took a more active form. In a series of encounters and interviews with the author between May 1996 and May $1997,{ }^{8}$ the position was articulated as a 'survival strategy' for the union leadership. Earlier, I highlighted the attempt to separate the Minister of Labour from his Fuhrer (Sani Abacha). This culminated in the August 1996 meeting, which senior officials of NLC affiliate-union (led by Adams Oshiomole and Sylvester Ejiofor) held with Sani Abacha. At this meeting allegiance to the regime was extracted from the unionists. From 1996 to May 1998, the encounter took the form of open collaboration. In 1996, Oshiomole and Ejofor were appointed members of the regime's Vision 2010 Corrimittee - which was to draw the regime's strategic development plan. In March 1998, Oshiomole was again appointed member of the regime's monitoring committee for capital projects contained in the 1998 Budget. $^{9}$ This took the more dramatic form in early 1998, when a widely reported interview, Oshiomole endorsed the campaign to have Sani Abacha stand as a sole candidate in the Presidential election slated for August 1998. An insight into the 
implications of this increasing acquiescence with the regime may be gleamed from an interview that Esther Kokori, wife of Frank Kokori-the General Secretary of NUPENG gave to a national daily in May $1997 .{ }^{10}$ Esther Kokori was quoted in the interview to have said:

All the so-called friends and labour people have deserted us. You need to see how they flocked here when he [Frank Kokori] was around but with his incarceration, most of the friends and comrades have disappeared. We don't see them again; even some of them are members of Vision 2010 Committee.

Frank Kokori's case is particularly instructive of the depth of personalised brutality to which the regime descended. Injuries sustained during the 46 months of detention and the condition of his detention was so severe that Kokori was forced into retirement less than a year after his release from detention after the death of Sani Abacha in June 1998. Spinal cord injuries that he sustained in detention went untreated. As Esther Kokori mentioned in the interview, despite that fact that "the spinal injury had become serious [and] he [was] always in pain" the regime denied him medical treatment in any hospital.

However, the response of the labour movement to the repression of the Sani Abacha regime has a flip-side: an upsurge in shopfloor militancy. If the intention of the regime was that its policies would produce a cowed and disorganised rank-and-file it failed. The reverse would seem the case - although the capacity for industry-wide or national challenge of the dictatorship was severely hamstrung.

Elsewhere, I drew attention to the trade disputes data for the pre-1995 period as possibly suggestive of labour politics where it mattered: i.e., on the shopfloor or workplace (Adesina, 2000:148). In Table $\mathrm{I}^{11}$, I have extended the dataset to 1998 - the year General Sani Abacha died - and added columns showing three-year moving averages of the dispute statistics. The three-year moving average gives trend information about each dataset but with the additional advantage that the data is smoothened. Given the huge fluctuations in many of the time series, I am inclined to using a 3-Year Moving Average, rather than a 5-Year Moving Average because it produces fewer losses in observation. ${ }^{12}$

The central argument in the earlier report of the Nigerian trade dispute statistics is similar to the one here- basically, that while the key members of the 1994 national leadership of the NLC moved into a relation of acquiescence with the neo-Fiihrer State, the trade dispute statistics - and 
Figure1: Trend in Strike Propensity and Average Striker Days (1980-1998)

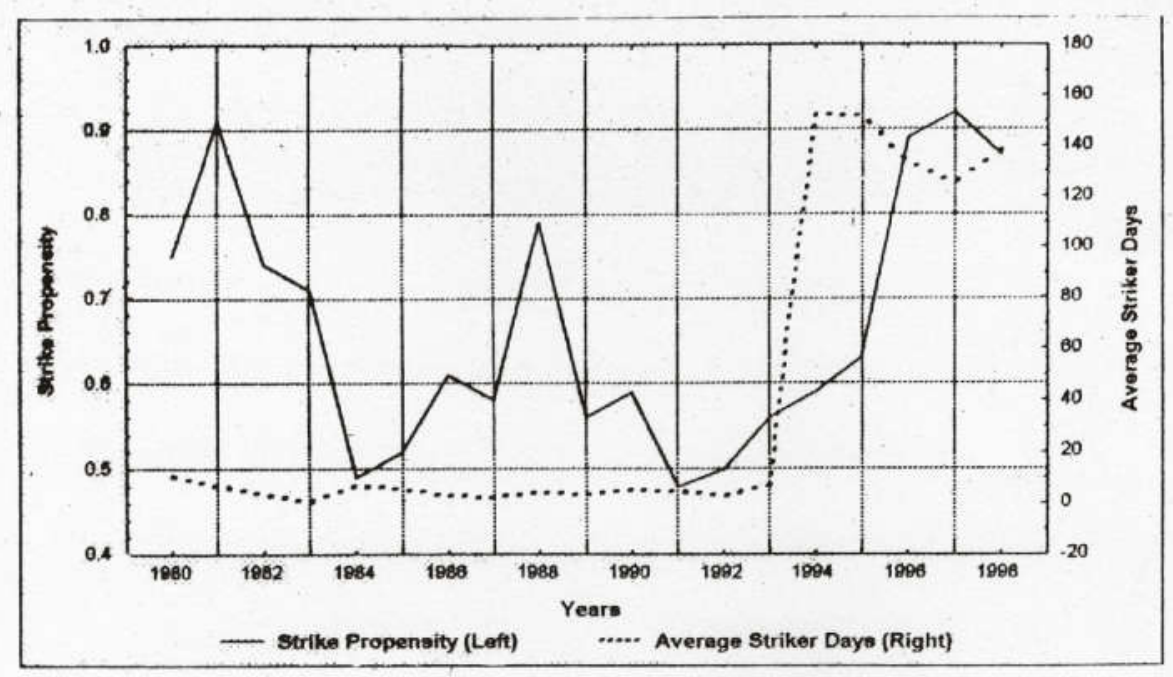

these are official data set - tell a different story: namely that of an upsurge in shopfloor militancy. The picture that emerges from the extension of the data to 1998 only goes to reinforce the argument. It is all the more significant when we consider the rampaging level of repression that the Abacha State unleashed on dissent in the country. It was not until the death of the neo-Fiihrer on 8 June 1998 that the repression abated.

Four main datasets demonstrate the sense of generalised (rather than isolated) upsurge, right into 1998. These are (a) the number of workers that were involved in various industrial actions, (b) the Striker Days or what is conventionally called 'Human Days Lost', (c) the associated data on the average striker days, and (d) Strike Propensity, i.e., the probability that a trade dispute will end up in strike action. This last statistic is a measure in proportions of one - a strike propensity of 0.92 suggests that a dispute, once declared, has a $92 \%$ chance of leading to a strike. It can be taken as a proxy for "intransigence," militancy, or poor dispute resolution procedure. In this specific case, while the strike propensity data may reflect the decay in the national trade dispute arbitration machinery, it also reflected the extent to which union activism became the platform for expressing opposition to the regime, and the reluctance to be entrapped in the arbitration mechanism that was tainted by the regime's overarching directive-control of machineries of the state. This was the sense in which many union activists saw it including the academic staff union to which I was privy. The disruption of national-level union activities in the case of the university academic staff meant that much of the resistance was expressed as campus-level disputes. In most of these cases, the university administrations acted, overtly, as little more than extensions of the Presidential Villa in Abuja. 


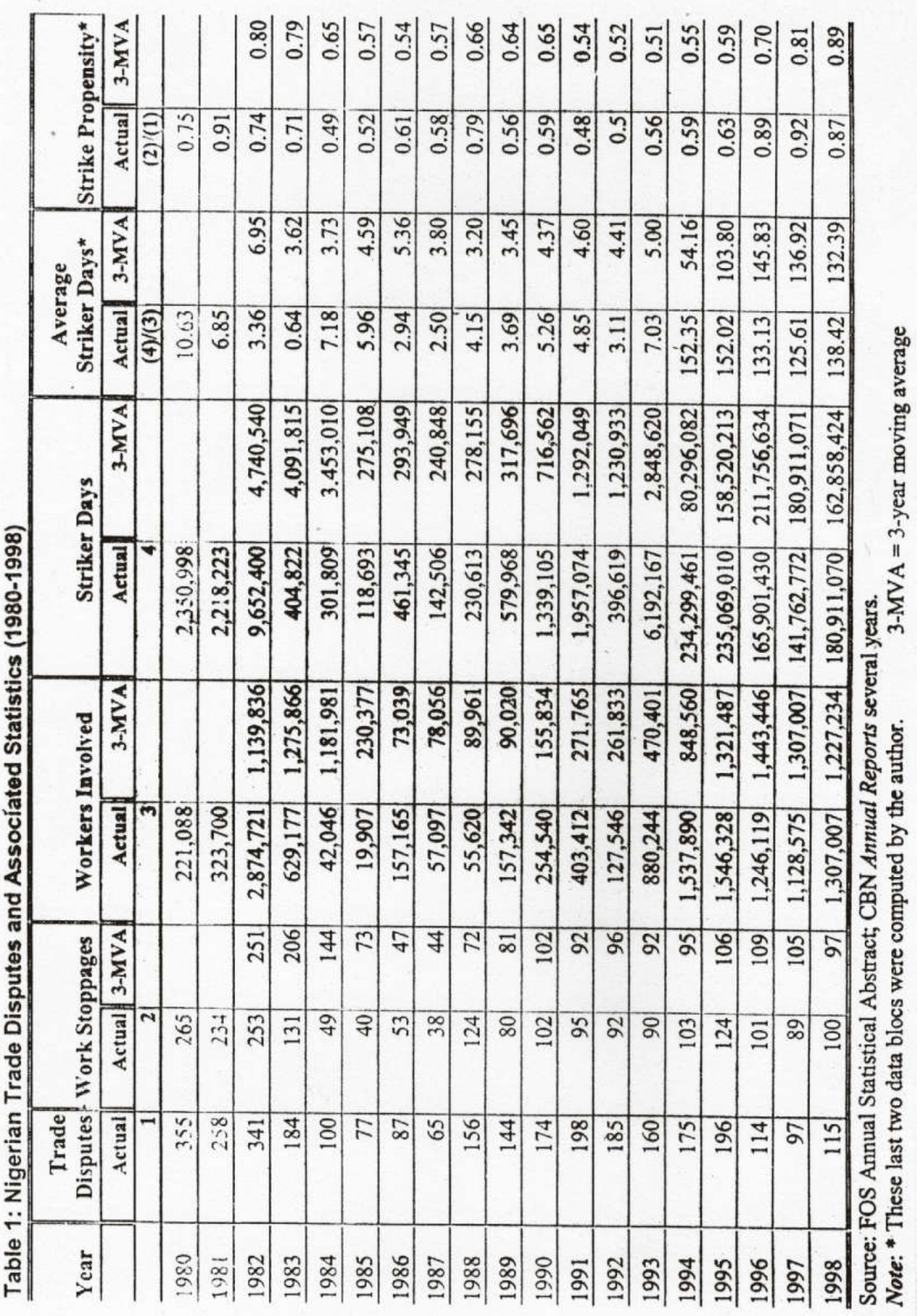


Table 1 shows that strike propensity accelerated in the period between 1995 and 1998. The 1997 figure shows that a trade dispute, once declared had a $92 \%$ chance of ending in a strike action; up from 50\% in 1992. The three-year moving average trend shows an average of $10 \%$ annual increase in this measure of industrial activism between 1995 and 1998. The trend in the number of workers involved in strike actions shows a sharp rise between 1992 and 1995 and a decline between 1996 and 1997, although it picked up again in 1998 - all of which is definitely not in the second-half of the yearafter Sani Abacha's “death. Again, even this small decline is more than ten-times the number of workers who went on strike in 1992. The nearest thing to the trend from 1994 to 1998 is 1982, the year of a major General Strike called by the NLC.

As Figure 1 shows, the sense of generalised shop-floor 'rebellion' is captured eloquently by the dataset on striker days and the average striker days- again well into 1998. Average striker days, or strike duration, were 3.11 days in 1992, about 5 months in 1995, and over 4-and-half months in 1998. While the total duration of strikes in 1992 was 396,619 day, it increased more than 590-fold in 1995. In 1998. it was a 455fold increase over the level in 1992. Not only were disputes more likely to lead to strike actions, strikers were likely to stay out longer on strike. It would seem, therefore, that while the national leadership was acquiescing with the regime and many unions at the national level withdrew from overt 'political' activism, workplace militancy increased rather than diminished. But this is a point that I understated in an earlier discussion (Adesina, 2000). and bears correcting here.

The absence of disaggregated trade dispute time series in the two-official sources used to compose Table 1 makes it difficult to apprehend the sectoral sources of industrial action, it is nonetheless important to acknowledge the following:

(a) The diversity of the workplace that the data represent, and therefore the sectoral distribution of the time series.

(b) The activism captured by the time series had to have been expressed within structures of trade unions - formal or informal. It is only in this sense that the Industrial Relations division of the Federal Ministry of Labour, responsible for compiling the data - would have recorded them as trade disputes and strikes. The national leaderships of the various unions, however, need not have sanctioned the strikes. Indeed, often as in the case of the National Union of Teachers the leadership declared its opposition to the strikes.

In other words - and this is a point I did not stress sufficiently before - the upsurge in what I call shopfloor rebellion or revolt was predominantly within formal trade unions organisations. Beyond the anecdotal, it is difficult to disaggregate the data into those that were 
manifestations of independent shopfloor revolts and those that involved the national leadership of the trade unions. An entirely different point concerns the issue of disaggregating the time series and avoiding 'heroic myth-making'. It bears stressing that not all who embarked on strike actions understand them as having subliminal political intention, nor were all the strikes inherently political-subliminal or not. In several cases, strikes were about arrears of unpaid salaries. In some cases, in the tertiary education sector, strikes called by administrative and support staff unions were directed at their academic staff counterparts, but this was largely in the pre-1994 and post-1998 periods. However, the fact that there is such a dramatic shift in the key measures of labour activism point to a major shift in the mood of the country - at the shopfloor as in the more activist sections of the civil society. It might be argued that the fact that activism took the form of industrial action rather than overt 'political' action suggests a withdrawal in the face of the repression of the neo-Fiihrer State. The difficulty with the argument would be to insist that resistance is valid only if it is overt and stated as such - which runs counter to what we know of human experience. That resistance takes a 'disguised' form does not make it any less an act of resistance nor is it unusual. That it is expressed in such a 'loud' manner - which the time series indicate - points to forms of response that separates the rank-and-file of NLC-affiliated unions and several white collar unions from that of senior officials of NLC-affiliated unions. Indeed, several public sector strikes, called by local shopfloor activists between September 1994 and 8 June 1998, were in defiance of national union leadership. Again, while some of the strikes that caught the popular imagination were by white-collar unions, this shop-floor militancy was a crucial aspect of the history of the period.

There was no doubt that several NLC-affiliated unions took the deliberate decision of non-cooperation with the government appointed administrator of the NLC - a case being the withholding of union dues to the NLC between September 1994 and August 1998. ${ }^{12}$ I would argue, however, that this was part of the same response to the Abacha regime outlined earlier: a combative attitude to the Minister of Labour, for instance, while looking up to Abacha to adjudicate between the union officials and the Minister. Indeed, senior NLC officials like Paschal Bafyau retreated completely from the trade union platform - indeed, he and his first Vice President, Mr Frank Oranmula, became active office seekers in Abacha's transition programme. The $2^{\text {nd }}$ Vice President, $\mathrm{Mr}$ Adam Oshiomole, illustrate the other type of response: while remaining in the labour movement, as the General Secretary of the Textile workers union sought a different mode of cooperation with the regime. By February 1998, as noted earlier, he was voicing public support for Sani Abacha's campaign to transform himself from military dictator to a civilian one. 
While behaviour modification impact of repression took the form of either covert or overt complicity with the neo-Ftihrer State, the response i from some white-collar unions mirrored the militant response that the data in Table 1 reflects. Here, we use ASUU as an illustration. Between 1989 and 1998, for instance, the academic staff union was banned on three different occasions (1989, 1992, and 1996). On each occasion the ban by the military regimes of Babangida and Abacha arose from sustained industrial dispute over funding of higher education, autonomy for universities, wages and conditions of service for university academics. Between 1992 and 1998, the union took the deliberate position of not taking the exercise of the executive power by the State as given - it was a deliberate decision of the union at all levels of operation to resist the bans. Often the union adopted a new name, e.g., Academic Staff of Nigerian Universities. The idea was that while the regimes could ban a union it could not ban the academic staff as a collectivity! In the legal case cited above, effort was made (successfully) to exploit the legal loophole in the instrument of ban itself, which allowed the union to exist in each university campus but not as a national organisation. Resources for financing the national operations of the union were collected from members of the union and remitted to the officials of the national union.

In addition, the resistance to the military was rooted in distinct contestation of the terrain for policymaking on higher education: there was very little doubt that the position of the union was stridently opposed to the neo-liberalism that underscored the policies of both the Babangida and Abacha regimes. The reprisal of the State was anticipated. In each case of industrial action, the period of dispute stretched from between two and seven months. In 1996, when the strike lasted from March to October, the directive from the government to the university administrations to stop the salaries of the academic staff took effect from April. In other words the strike was at considerable personal cost to the individual members, apart from the arrest and detention of several national and local branch leaders.

The repression was, however, not without cost to the union. While the local branches continued to exist on several university campuses and clandestine meetings of the National Executive Committee continued, by 1998 the number of delegates attending the meetings had declined significantly. This was due in part to the various university administrations taking advantage of the repression of the State to sustain local repression of their own - and the capacity of the local branches to thrive depended on local campus traditions and organisational capacity. It also mirrored the increasingly fragmentation of national politics and the 'ethnicisation' of the resistance to the regime. Attendance at national council meetings and check-off remittance (for sustaining the staff of the national office and activities of the officials) came in the main from the universities in the Southwest of Nigeria. This, I will argue, is both a measure of the 
organisational experience from some of these campuses - that created a network to sustain weaker branches - but also a measure of a more conducive political environment of opposition to the regime in the region. The resistance to the Abacha regime was deeper and more widespread than in most other parts of the country, and support within the university and local communities much more. The capacity of university administrations on the campuses to initiate repression, at the behest of the regime, more greatly constrained. A case is the rejection by Senate of University of Ibadan of the Vice Chancellor's nomination of the Secretary to the Federal Government for the award of a honorary degree in 1997. It was the sustained pocket of mobilization on these campuses that gave force to the speed with which the union regained the initiative in its dispute with the post-Abacha governments.

\section{Conclusion}

In the preceding pages, I examined the dictatorship of Abacha regime from the perspective of its labour policies. I argued that the basis of neo-fascism was laid by the politics of adjustment, which saw a "strong state" as essential for implementing the adjustment programme. It was in this context . of international acquiescence that military dictatorship flowered under the regime of Ibrahim Babangida. The shift in the nature of dictatorship under the Abacha was both qualitative and a continuation. A clear objective of the neoFiihrer state was to reconstitute civil society into a pliant agency: something that was most evident in the labour policies of the regime. The response from die labour movement, as I argued, was dual: acquiescence and cold complicity on the part of national union leaders - in which some bought into the regime's project of reconstituting the civil society. On the other hand was the heightened militancy from the shop-floor and some white collar unions. While there is much that is reported about the political roles of the white collar unions, the implications of the shopfloor militancy of the period in the narratives of the political history of the time is often poorly understood and documented. This is not only a question of ordinary people's resistance to a repressive regime, and their place in the history of the time; it is also about the need to enter a corrective to the historiography of the period.

\section{Endnotes}

1 For a longer discussion of the issues around the neo-Fuhrer agenda of the Abacha regime, see Jimi O. Adesina, 1998, "Civil Society and the Abacha State", Quarterly Review of Economy and Society, Vol.1, No.3, Jan-March, (Lagos). An earlier and larger version of the paper was a text of a lecture at Queen Elizabeth House, Oxford on 22 November 1997. 
NUPENG: The National Union of Petroleum and Natural Gas Workers of Nigeria; PENGASSAN: Petroleum and Natural Gas Senior Staff Association of Nigeria.

The decree was similar to another from the 1970s. In 1975, when the military regime launched its onslaught against the trade union movement, the unions were barred from affiliating with all international labour organisations arid trade secretariats. The only exceptions then were ILO and OATUU. From its inception, the NLC and the trade unions operated within the framework of such prohibition of affiliation. As to be expected the trade unions found ways round the prohibition. What was new about Decree 29 is that it added the ILO to the

list of organisations to which unions could not affiliate or relate.

Justice R.A. Kasim Ruling in Suit No.FHC/E/28/96; Dr. G.O.S. Amadi and others (Plaintiffs/Respondents and University of Nigeria, Professor Umaru D. Gomwalk (Defendants/Applicants) on Tuesday $15^{\text {th }}$ day of April 1997,

One should note that in the period leading to and after Nigeria's 'summer of discontent' in 1974, several in the leadership of the movement took a placid approach to the regime. The irony of the ban on NLC, NUPENG, and PENGASSAN is the hostility of the leadership of the NLC leadership to the strikes.

An elaboration of this theme is the subject of Adesina (1997).

Non-formal interviews took place in May 1996 and -1997-both at the Frederich Ebert Foundation May Day workshops, and January 1997 in Kano with a deputy general secretary of a Kaduna-based private sector union.

See The Post Express edition of 27 March 1998. http ://www. postexpresswired. com. “Kokori's Wife Lambasts Labour Leaders", The Post Express edition of $3^{\text {rd }}$ May 1997. As explained in Adesina (2000), the data in Table 1 are in two categories. The first category involves: the number of trade disputes, work stoppages, number of workers going on strike, and "man-days lost". These are drawn from official dispute statistics drawn from the Federal Office of Statistics' Annual Statistical Abstract and the Central Bank of Nigeria's Annual Report. The second category are 'average striker days' (the average length of the work stoppages), and 'strike propensity' (the probability that a trade dispute, once declared will

end up in strike action). The author computed both. As explained elsewhere, I use 'striker days' rather than the official idea of '(hu)man-days lost', which as Richard Hyman pointed out is misleading. Matters of strike statistics have been discussed fairly in detail elsewhere (cf. Adesina 1992).

My appreciation to Dr Asrat Tsegaye — of the Department of Economics and Economic History at Rhodes University (East London Campus) - against whom I bounced some of the ideas here.

See The Post-Express, 14 August 1998 and 27 September 1998 editions (http://www.postexpresswired.com/postexpress.nsfy 


\section{References}

Adesina, J., 1998, "Civil Society and the Abacha State", Quarterly Review of Economy and Society, Vol.1, No. 3, Jan-March .

Adesina, J., 2000, "Adjustment and the transformation of labour identity: what's new and does it matter?" in Attahiru Jega, (ed.), 2000, 'Identity transformation and identity politics under Structural Adjustment in Nigeria, Uppsala: NAI.

Adewumi, Funmi and J. Adesina, 1999, "Occupational Groups" in Oyediran, O. \& Adigun Agbaje (eds.) Nigeria: Politics of Transition and Governance 19861996.Dakar: CODESRIA Books.

Ake, Claude, 2000, The feasibility of democracy in Africa. Dakar: Codesria Book Series.

Federal Office of Statistics, 1996, The Nigerian Household 1995: Summary of latest results from the National Integrated Survey of Households, Lagos: FOS.

Havenik, K. and B. van Arkadie (eds.), 1996, Domination or Dialogue: experiences and prospects for African Development Co-operation. Uppsala: The Nordic Africa Institute.

Lebeau, Y. and'Mobolaji Ogunsanya (eds.), 2000, The Dilemma of Post-Colonial Universities, Ibadan: IFRA/ABB.

Olukoshi, Adebayo, (ed.), 1998, The Politics of Opposition in Contemporary Africa. Uppsala: Nordiska Afrikainstitutet.

Otobo, D. 1981, “The Nigerian General Strike of 1981," Review of African Political Economy, 22.

Otobo, D., 1992a, "State and Labour: the 1988 ban of the NLC" in D.

Otobo (ed.) Labour Relation in Nigeria Vol.1, Lagos: Malthouse.

Otobo, D., 1992b, "Organized Labour and Political Process in Nigeria", in

D. Otobo (ed.), Labour Relations in Nigeria Vol. J, Lagos: Malthouse.

Therborn, G., 1980, The ideology of Power and the Power of Ideology, London: Verso.

Toye, John, 1990, "Interest Group Politics and the Implementation of Adjustment Policies," Paper presented at UNRISD/SIAS/CMI Joint Symposium, Bergen, 1719 October.

Williams, Gavin, 1994, "Why Structural Adjustment is Necessary and Why it Doesn't Work", Review of African Political Economy, No.60.

World Bank, 1994, Nigeria: Structural Adjustment Program, policies, implementation, and impact. (West Africa Department, Country Operations Division), Report No. 13053-UNI, May 13.

World Bank, 1995, Labor and the growth crisis in sub-Saharan Africa. (Regional Perspectives on World Development Report 1995).Washington, D.C.: World Bank. 